\title{
Major/Minor in World Literature
}

\author{
Theo D'haen, KU Leuven)
}

\begin{abstract}
This article appears in Journal of World Literature 1.1 (2016), pp. 29-38. When citing please refer to the printed version.
\end{abstract}

When it comes to literature in general and "world literature" in particular, do we apply the terms "major" and "minor" to singular works, authors, literatures? Do we interpret them in a quantitative or a qualitative way? And does the distinction matter? The response to the latter question depends on the particular interpretation one puts on the term "world literature." If, with some of the early interpreters of the term, one takes it simply to mean all literary works ever written in the world, the distinction collapses. Such "universal literature," in the words of Albert Guérard in his 1940 Preface to World Literature, "embraces all literatures, of all ages, in all languages, without insisting on their unity or their relations" (Guérard 1940, 15). In his The Challenge of Comparative Literature Claudio Guillén reformulated this as "the sum total of all national literatures," and labeled it "a wild idea, unattainable in practice, worthy not of an actual reader but of a deluded beekeeper of archives who is also a multimillionaire" (Guillén 1993, 37). David Damrosch in What is World Literature concludes that for any such totality as Guillén refers to, the blanket term "literature" would suffice, and that therefore "the idea of world literature can usefully continue to mean a subset of the plenum of literature" (Damrosch 2003, 4). Damrosch's subsequent definition of world literature as "all literary works that circulate beyond their culture of origin, either in translation or in the original," in fact comes down to updating for a globalizing world earlier and more narrowly nationalistic and Eurocentric definitions of world literature. Yet the question of the "minor" literature or author in the new global world order is far from settled.

Guérard saw world literature as "limited to those works which are enjoyed in common, ideally by all mankind, practically by our own group of culture, the European or Western" (Guérard 1940, 15). For Richard Moulton, the first scholar to devote an entire book to World Literature and Its Place in General Culture, in 1911, world literature is "Universal Literature seen in perspective from a given point of view, presumably the national standpoint of the observer," (1921, p. 6) which in his case meant "the English-speaking peoples" (Moulton 1921, p. 9). Damrosch side-steps the hierarchical principle inherent to Moulton's and Guérard's approaches by claiming that "world literature is not an infinite, ungraspable canon of works but rather a mode of circulation and of reading, a mode that is as applicable to individual works as to bodies of material, available for reading established classics and new discoveries alike" (Damrosch 2003, 5). From this perspective, the particular subset of "[universal] literature" qualifying as world literature could in principle consist of an individual scholar's reading of a work, any work whatever, from beyond that scholar's own culture of origin. In many ways this rather resembles the actual practice of Goethe when he unleashed the idea of Weltliteratur upon the world in 1827. However, when Damrosch, mindful of Guillén's "actual reader," posits that "a work only has an effective life as world literature whenever, and wherever, it is actively present within a literary system beyond that of its original culture" (Damrosch 2003, 4), it is clear that he means works that reach beyond the individual scholar or occasional reader. This is where the distinction "major" and "minor" 
becomes meaningful for determining what will be included and excluded in "world literature."

Theoretically, an emphasis on works' effective life abroad opens the door to a purely quantitative approach. The greater the number of readers a work has beyond its culture of origin the more "major" it might then be thought to be. This criterion would fit both "classics" such as Virgil's Aeneid, Cervantes's Don Quijote or Tolstoy's War and Peace, and presentday bestsellers by thriller author Don Grisham, popular romance writer Nora Roberts, or popular Latin American magical realists Paulo Coelho or Isabel Allende. If we enlarge our criterion of what "literature" actually is, reaching beyond the narrowing of the term since roughly - the turn of the nineteenth century to what previously went under the heading of "belles lettres," or in more contemporary terms, "creative literature," we could include the Bible as well. However, as Fritz Strich warned in his 1930 article "World Literature and Literary History," "there is a ... deeper concept of world literature that comprises not just a spatial but also a temporal dimension" (Strich 2013, 41). World literature, he contends, "is precisely that literature that has not been forgotten and that has not sunk below the horizon, even if once it may have enjoyed the widest dissemination and influence" (Strich 2013, 41). Strich's own examples of the "sunk" are Augustus von Kotzebue, a German contemporary of Goethe's, the turn of the twentieth century German author Hermann Sudermann, and the prolific early twentieth-century English crime and adventure writer Edgar Wallace, all of whom in their own day enjoyed immense popularity also beyond their culture of origin because, Strich contends, they joined topical relevance to easily digestible form. To truly belong to world literature, what is needed beyond sheer breadth of "dissemination" and "supranational importance" are "duration" and "lasting validity" (Strich 2013, 41), both of which devolve from a work's "eternal relevance" (Strich 2013, 40). A happy example of a combination of topical with eternal relevance, dressed in a popular and easily digestible form (at least at its moment of appearance), is Goethe's Werther. "It is quite possible, "Strich admits, "that there are breaks in the total period of time that a work or an author enjoys world literary status ... a work or a writer may become suppressed by a particular period movement, and temporarily forgotten ... but when the work or author really is of lasting value, it or he will always again, when its hour has struck, emerge from the river of forgetfulness, as happened with Shakespeare and Cervantes" (Strich 2013, 41). Clearly, the criterion of quantity is here amplified with the criterion of quality; of those works, and their authors, that stand out because of their wide dissemination it is only those that also show the extra qualities enumerated by Strich that qualify as "major," and therefore as worthy of belonging to world literature.

The works Strich has in mind can effectively come to be part of world literature in three ways, or perhaps it would be better to say that they can come to figure in three different concepts of world literature. The first, Guillén's "wild idea" of "the sum total of all national literatures," has actually been attempted in the form of a number of world histories of literature. This "genre" was particularly popular during the nineteenth century in Germany, but also during the twentieth century there appeared a number of such, usually multi-volume, histories in - to my knowledge, but there may well be other examples - Scandinavia, Italy, Spain, France, and Russia. The second concept corresponds to what we may call a "unified canon" of world literature, either in the form of a history that pretends to treat the "major" works of the world's literatures not in their respective national contexts but from a "global" perspective, or in the form of an anthology. The third concept takes up Damrosch's idea of world literature as a "mode of reading: a form of detached engagement with worlds beyond our own place and time" (Damrosch 2003, 281). It will be clear that for all three concepts a division of works into major and minor is inevitable. 
World literature as either a synchronic snapshot or a diachronic history of the world's literatures only turns into the practical impossibility Guillén claims it to be if in fact we disregard his own reference to "national literatures." In practice, each national literature, at the hands of its own critics and literary historians, divides into a number of works that are deemed worth reading both from a contemporary and a historical point of view, and hence can be considered "major," in contrast to those that are not, or are less so, and are therefore seen as "minor" if they are considered at all. The contemporary perspective may to a certain extent coincide with the "spatial" or "dissemination" dimension mentioned by Strich, but it will equally foreground a number of works of more limited dissemination but that are valued highly by contemporary critics, for whatever reason. The historical perspective may well take into account aspects of wider or more restricted dissemination of a particular work at given moments, but will probably focus more on the "quality" argument developed by Strich. World literature, then, as the sum total of national literatures in the form of a contemporary survey, a world history of literatures, or an anthology, in its most simple guise would consist of the juxtaposition of all the world's literatures' self-evaluations.

In practice again, although not quite the wild thing Guillén invokes, the result would be - to say the least - unwieldy because hopelessly voluminous. Therefore, even a world survey of contemporary literature, a world history of literature, or an anthology based on the juxtaposition of national literatures would resort to a further and more stringent selection in terms of major and minor, with most probably all works categorized as minor in a national literature survey or history being omitted altogether, and even a fair number of works labeled major in such national literature surveys and histories falling by the wayside. However, this is most probably not where the selection process stops. Theoretically, in such world literature surveys, histories, or anthologies one could envisage equal space being given to all literatures. In practice, however, such will not be the case, and the space given to specific literatures will once more depend on whether such literatures in themselves are considered as major or minor. This, of course, is not a new insight: in a brief article that may well be said to have started the entire major/minor discussion, the Danish critic Georg Brandes (2013) already at the turn of the twentieth century pointed at the uneven playing field of Weltliteratur. The net result will be that from those literatures eventually categorized as minor, a greater proportion of works regarded from their own internal or national point of view as major will be weeded out than from those literatures that are considered major. The same thing holds if the principle of simple juxtaposition is abandoned in favor of that of integration into a more unified or global arrangement.

Whether a literature itself qualifies as major or minor depends on a number of factors, which may be weighed differently according to different criteria. Here again the issues of quantity and quality crop up. One of the most obvious criteria would be the number of users of a given literature's language. According to this criterion, both synchronically and diachronically, Chinese literature would assume pre-eminence. As soon as one starts looking for the next contenders, however, one runs into difficulties. According to Nicholas Ostler, in Empires of the World (2005), the ten most widely used languages in the world today are, in descending order, Chinese, English, Hindi, Spanish, Russian, Bengali, Portuguese, German, French, and Japanese. Ostler stipulates, however, that his ranking concerns "speakers as first or second language" ... In other words, for English and to a lesser extent also French, German, Russian, and Spanish, language use, especially as a second language, does not unequivocally map onto a specific nation or culture. Conversely, there are some languages not mentioned by Ostler that do map onto a specific nation, such as the Bahasa Indonesia used throughout Indonesia as the government-imposed lingua franca for a multi-lingual country of more than 250 million. 
A further complicating factor is that if one looks at the world's literatures from the perspective of the sum total of national literatures as related to language, there are a number of countries that do not have a "national" language of their own - think of Austria, a Germanlanguage nation but definitely distinct from Germany itself, or multi-lingual countries such as Canada, with English and French, or Switzerland, where German, French, Italian and Romansch are used, or Belgium, with Flemish (a regional variant of the Dutch used in The Netherlands), French, and German. Conversely again, within countries boasting a "national" language there may be minorities using a different language, with a literature of its own. This is the case, for instance, of The Netherlands, with its small Frisian-speaking minority, but the list of such countries is large indeed. Whatever their particular situation, almost all such "exceptional" literatures would be categorized, both synchronically and diachronically, as minor, or overlooked altogether. Not coincidentally all the "exceptional" examples I have hitherto mentioned concern small countries. The case is very different for "big" countries sharing a major language, most often with a former European colonial mother country, for instance the United States and the United Kingdom (or in its earlier guise Great Britain), Brazil and Portugal, or Spanish America with Spain, although notice that in the latter case the reference is not to individual Latin American countries using Spanish but rather to their conglomerate, each of them separately in fact hovering somewhere between major and minor status. Such bigger entities usually quite easily manage to hold their own.

Still, even if one looks at national literatures mapped onto the countries whose national language they use, one notices a sharp divergence in the fates these literatures suffer, and especially how they have suffered from a world literature perspective. In fact, in most world histories of literature, hitherto without exception products of the Western world, nonEuropean literatures were routinely neglected especially in their more modern manifestations, with attention given almost exclusively to early mythical and religious writings. But even between Western, more specifically European literatures, treatment has been unequal. Concretely, French, English, and German literature, and to a lesser extent Italian and Spanish literature, next to literature in ancient Greek and in Latin, have received the lion's share of attention and space. Obviously, then, other criteria are again in play here. These we can best sum up under the heading "literary capital" as used by Pascale Casanova (2005). Part of Casanova's literary capital are the resources and prestige of the language the literature in question uses, the age of the literature in question, the number of writers and works it contains, the number of national "classics" it can boast, the strength of its literary system: writers, literary agents, publishers, critics, translators, and its centrality in a wider system of circulation transcending its own linguistic/literary system through translation, selection, and evaluation. The literary capital that accrues to a particular literature in turn enhances the linguistic capital of the language in question.

Not surprisingly, those literatures that have hitherto set the tone for world literature are those that Casanova also sees as successively having satisfied, for their own times, the combination of requirements making up her definition of literary capital: Latin literature throughout Roman antiquity, and especially the period of Empire, and then throughout the Middle Ages and into the Renaissance, Greek literature as precursor and model for Latin literature and retrospectively in its own right again as of the rise of Renaissance Humanism and philology, Italian literature as the prime vehicle of the Renaissance, followed by Spanish literature and French literature, and then English and German literature as the countries or nations using the corresponding languages gained prominence on the military, political, economic and finally the cultural scene of Europe, and eventually the world. All other European literatures are minor, and even Italian and Spanish literature become relatively minor as we near the present, precisely because they couldn't maintain their position in the 
economic, political, and cultural/literary pecking order beyond the periods in which the regions they originate from were dominant.

It is especially Europe's "outliers," though, that seem condemned to permanently remain minor, even if they can claim a good deal of both quantity, in terms of population but also literary production, and even of literary and cultural capital, as Marta Skwara (2015) argues with respect to Polish literature and its four Nobel Prize laureates. Following this same logic, American, which is to say United States, literature should by now have joined, or should be about to join, the club of major literatures, although it seems to me that the verdict is still at least partially out on this. The reason for this may well be that although American literature satisfies a number of Casanova's criteria, it is deficient in for instance the issues of age and of national classics recognized also as world classics, as well as in its centrality when it comes to circulation of other-language literatures through translation. The same thing applies to Latin American literature, both conjoined Spanish-American and Brazilian.

For the same reasons that American literature has been on the rise since the beginning of the twentieth century, other literatures now seem poised to join the majors club, with some of them actually having better assets than American literature. Chinese literature can not only claim the advantage of numbers; it also has the backing of a fast-growing economy with an already global reach, supported by a rapidly increasing political and military presence, and an ambitious cultural policy aiming at popularizing the Chinese language through the worldwide proliferation of Confucius Institutes. Perhaps equally importantly, it has the age and the number of national classics that enable it to immediately step up to the plate once a sufficient number of other literary capital requirements are met. The same thing, though to different degrees and according to different time frames, holds for Japanese, Indian (either considered as one entity or in its various linguistic avatars, including its ancient ones), Arabic (again either as one entity or in the guise of various national literatures), Persian (both in its contemporary Iranian guise but even more so as the literary language of much of the Muslim world for centuries), and possibly other non-European-language literatures. Depending on how the world evolves, Indonesian literature may assume the status of a major literature, again either in the guise of a "national" literature comprising next to its national literature in Bahasa Indonesia also various literatures in different languages, or through those of these literatures with most cultural/literary capital, such as Javanese for instance. The same thing may happen with South African literature, and with various Asian literatures hitherto unmentioned.

Conversely, and as is already happening today, the status of French and German literature may sink, at least in relative terms. In fact, what we may well see happening is an evolution whereby the divisions in national literature are superseded in favor of their amalgamations into larger entities, as is for instance the case in a multi-volume world history of literature now in progress (Pettersson and D'haen, 2011) that, not entirely unproblematically, approaches the world's literatures from a continental or sub-continental perspective (for Asia, for example), with European literature occupying a place not markedly different from other continental or sub-continental entities in terms of space devoted to it. The same thing, combined with a thematic and period approach allowing for easy border-crossing between the most diverse literatures, and hence for greater leeway when it comes to bypassing works that are major in their national context, we see with the more recent anthologies of world literature such as the Longman 2004 and the Norton 2012. Still, if in these more recent approaches the previous imbalance between the literatures of Europe and those of the rest of the world is to a large extent remedied, in practice the fact remains that in the now concomitantly reduced space left for European literature it is those few literatures that in earlier approaches to world literature took pride of place as major continue to do so today. 
Finally, we turn to Damrosch's world literature as a mode of reading. As mentioned before, this in principle allows for a non-selective and non-hierarchical approach to the issue. However, when we see that the two other parts of Damrosch's threefold definition of world literature are 1) world literature is an elliptical refraction of national literatures, and 2) world literature is writing that gains in translation (Damrosch 2003, 281), the distinction major/minor comes into view again. Damrosch argues that a world literature reading of a given work would yield a different result from a reading of the same work within its national context. In theory again this holds true for any work, but in practice the results obtained will be more contrastively interesting with works that are major in the national literature context. And for a work to be translated at all, the principle of selection is a prerequisite. In practice, then, Damrosch's approach too will most often favor the major rather than the minor work. Still, a reading strategy approach does offer at least the possibility of studying both minor works from major literatures, and any work from any minor literature ("minor" in the sense I have given to it throughout this essay, not in the sense of Deleuze and Guattari), in a world literature context. This is precisely one of the aims of the Bloomsbury series "Literatures as World Literature" under the general editorship of Thomas Beebee. The first volume in that series, German Literature as World Literature, studies the refraction of a number of German works of literature throughout the world's literatures. Similar volumes, on other literatures, will undoubtedly follow. I will be curious to see, though, whether here again it is not the major literatures, such as German, that more easily lend themselves to such an exercise than the minor ones. From the latter I would not be surprised to see that it is only what Thomsen (2008) has called the "lonely canonicals" that truly "refract" into world literature.

In world literature, then, there seems to be no getting away from major/minor questions, even if they are made into the very crux of the argument and dedicated efforts are made to counter the hegemony of the majors, as Manuel Brito (2015) does when he demonstrates how a bevy of small poetry presses has sprung up around the world with the express purpose of disseminating, through translation, the literary production also of the minors. Most probably we will have to accept the inevitability of the occlusion of minor literatures such as Dutch for most practical purposes of anthologizing or comprehensive literary historiography, while at the same time remain vigilant to keep from congratulating ourselves prematurely on our cosmopolitan grasp of all the world's great books. The latter is a task that the Journal of World Literature seems particularly well situated to take up; in fact, for future volumes of the journal there are already issues planned on Romanian literature and on "ultra-minor" literatures. 


\section{WORKS CITED}

Beebee, Thomas. 2014. German Literature as World Literature. New York and London: Bloomsbury.

Brandes, Georg. 2013 [1902]. "World Literature.” In D’haen, Theo, Domínguez, César and Mads Rosendahl Thomsen, Ed. World Literature : A Reader. London and New York : Routledge, 23-27; originally in Samlede Skrifter, vol. 12. Copenhagen: Gyldendal, 2328.

Brito, Manuel. 2013. "Small Presses and the Globalization of Poetry." In Theo D'haen, Iannis Goerlandt and Roger D. Sell, Ed. Major versus Minor? Languages and Literatures in a Globalized World. Amsterdam : John Benjamins, 243-58.

Casanova, Pascale. 2004. The World Republic of Letters. Transl. M. DeBevoise. Cambridge, MA: Harvard University Press.

Damrosch, David. 2003. What Is World Literature? Princeton and Oxford: Princeton University Press.

Guérard, Albert. 1940. Preface to World Literature. New York: Henry Holt and Company. Guillén, Claudio. 1993 (1985). The Challenge of Comparative Literature. Transl. Cola Franzen. Cambridge, Mass: Harvard University Press.

Longman Anthology of World Literature. 2004. David Damrosch, David L. Pike, et al. Eds. New York: Longman.

Moretti, Franco. 2004 (2000). “Conjectures on World Literature.” In Debating World Literature. Ed. Christopher Prendergast. London: Verso, 148-162; originally in New Left Review 1 (January-February 2000): 54-68.

Moulton, Richard. 1921 (1911). World Literature and Its Place in General Culture. New York: The Macmillan Company.

The Norton Anthology of World Literature. 2012. Third Edition. Puchner, Martin, Suzanne Conklin Akbari et al. Ed. New York: W. W. Norton \& Company.

Ostler, Nicholas. 2005. Empires of the World: A Language History of the World. New York and London: Harper.

Pettersson, Anders and Theo D'haen. 2011. "Towards a non-Eurocentric History of World Literature." In Marc Maufort \& Caroline De Wagter, Ed. Old Margins and New Centres: The European Literary Heritage in an Age of Globalization/Anciennes Marges et Nouveaux Centres: L'héritage littéraire européen dans une ère de globalisation, Brussels, Bern, etc.: Peter Lang, 43-56.

Skwara, Marta A. 2015. 'Between 'Minor' and 'Major': The Case of Polish Literature." In Theo D'haen, Iannis Goerlandt and Roger D. Sell, Ed. Major versus Minor? Languages and Literatures in a Globalized World. Amsterdam : John Benjamins, 25970.

Strich, Fritz. 2013 (1930). "World Literature and Comparative Literary History.” In D'haen, Theo, Domínguez, César and Mads Rosendahl Thomsen, Ed. World Literature : A Reader. London and New York : Routledge, 36-49 ; originally as "Weltliteratur und Vergleichende Literaturgeschichte" in Philosophie der Literaturwissenschaft, Emil Ermatinger, Ed., Berlin : Junker and Dünnhaupt, 1930, 422-41.

Thomsen, Mads Rosendahl. 2008. Mapping World Literature: International Canonization and Transnational Literatures. London and New York: Continuum. 